\title{
Growth rate determination of the endangered mahseer, tor tor (hamilton 1822) from the bundelkhand region, central India.
}

\author{
Prakash Nautiyal $^{1}$, Amitabh Chandra Dwivedi ${ }^{2 *}$ \\ ${ }^{1}$ Department of Zoology, H.N.B. Garhwal University Srinagar, Garhwal-246174, Uttrakhand, India \\ ${ }^{2}$ Department of Zoology, Nehru Gram Bharati, Prayagraj, Uttar Pradesh, India
}

\begin{abstract}
Mahseer, various species of which abound in pristine clear waters of hill streams, rapids and fast flowing rivers, face numerous anthropogenic pressures their range of distribution. Age composition was recorded by obtaining samples of Tor tor during 2003-2004 from the market along the rivers Ken, Paisuni and Tons (Bundelkhand region). The age of fishes was recorded to be $6+$ in the Ken and Paisuni rivers while 8+ in the Tons river. The mean length for in $1+$ age was 20.2, 22.8 and $20.8 \mathrm{~cm}$ for the Ken, Paisuni and Tons rivers, respectively. The Paisuni river more is hence suitable for growth of T. tor. The formation of growth ring occurred annually.
\end{abstract}

Keywords: Mahseer, Tor tor, Age, Mean length, Growth rate, Bundelkhand region.

Accepted on May 06, 2021

\section{Introduction}

Out of 73 cold water fishes recorded in India, the mahseer are the most important group [1-3]. Tor tor is found in all the Vindhyan river systems of like Narmada, Tapti, Mahanadi, Chembal, Betwa, Sone, Ken, Tons, Paisuni and others [4-6] and lower reaches of the Himalayas which receive snow-melt water directly from water-sheds and in some upland waters of the Deccan plateau [7]. They prefer torrential streams with oxygenated water and rocks pools with gravel. Among Indian mahseer, T. tor is the most important food and game fish of India after $T$. putitora $[6,8]$. It constitutes an outstanding fishery in the Narmada and Ken rivers in Central India. It has also settled in some Indian reservoirs which have been stocked with this fish [9].

It is prefer torrential streams/rivers with oxygenated water and rocky pools with gravel and avoid very cold water [7]. Presently it occasionally appears in the catches from the Paisuni and Ken rivers (Bundelkhand region) [10-11]. In general, mahseer are declining very rapidly in their numbers and size in central India due to overexploitation, water pollution, habitat destruction, domestic effluent and insecticide and pesticide and many other stressors [2,8,9,12-15].

Accurate fish growth rates are important for growth analysis, age structure analysis and mortality rate estimation. The information of fish growth increment is also necessary to perceptive a species life history, reproductive biology, population dynamics, biomass and fisheries sustainability [8,16-17]. The age and growth study was conducted by [9] in the Narmada river and [18] in the Lake Bhimtal (Uttrakhand). But nothing is known for the Ken, Paisuni and Tons rivers that are a part of the Yamuna and Ganga river system in the Ganga Plains.

\section{Materials and Methods}

Present study was conducted in the three rivers i.e. Ken, Paisuni and Tons rivers, Bundelkhand region. The Ken and Paisuni rivers are right bank tributary of the Yamuna river. The Tons river is a right bank tributary of the Ganga river. Fish samples of $T$. tor (Tor mahseer) were collected seasonally during 2003-2004 from the rivers Ken, Paisuni and Tons. The scale method has been used for estimation of age and growth in the present investigations. The key scales were removed from the row above lateral line and below dorsal fin region [19-20]. The scales were cleaned in $5 \% \mathrm{KOH}$ solution to remove adhering- tissues and finally washed in distilled water. The scales were then pressed while drying in order to avoid their curling. The season with "minimum width in the terminal part of the anterior field of the scale" was designated as the period of ring formation. Since this condition occurred only once a year, the ring was designated as annuli. Total length and growth rate were recorded as differences between-at-age.

\section{Results and Discussion}

T. tor possess a typical cycloid scale. The formation of annuli occurred annually. The regular alternation of opaque and translucent zones in scale and whole scale of younger and older mahseer was also suggestive of annual periodicity. The scales depicting age are presented in Plate 1 (Figure 1).

The fishes of $6+$ age group occurred in the Ken and Paisuni rivers and $8+$ in the Tons river. The mean length was maximum in juvenile stage in the Paisuni river compared to Tons and Ken rivers. The maximum growth rate was recorded in the Tons river in adult and old stock (Table 1). 
Citation: Nautiyal P,Dwivedi AC. Growth rate determination of the endangered mahseer, tor tor (hamilton 1822) from the bundelkhand region, central India. J Fish Res 2021;5(3):1-4.

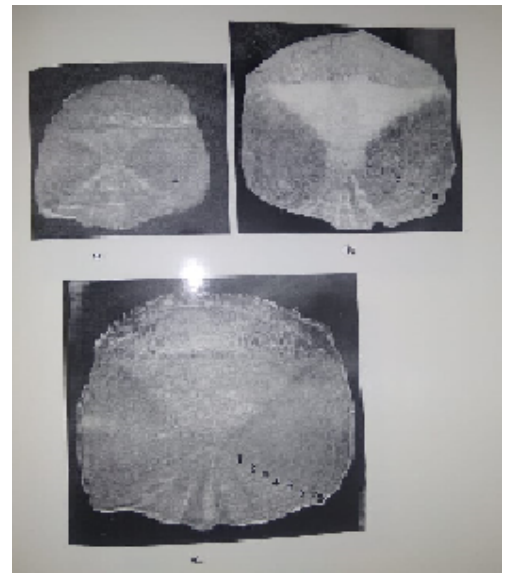

The growth compensation was recorded in $7+$ and $8+$ age classes form Tons river fishes. The growth rate in the Ken river were $20.2,11.6,8.0,7.9,7.2$ and $6.1 \mathrm{~cm}$ from $1+$ to $6+$ age groups. The growth rate observed for the Paisuni river was $22.8,12.5,8.4,7.5,7.4$ and $6.7 \mathrm{~cm}$ from $1+$ to $6+$ age groups. Similarly in the Tons river 20.8, 12.0, 10.1, 8.2, 7.3, 7.0, 7.8 and $8.8 \mathrm{~cm}$ from $1+$ to $8+$ age was observed. These growth rates indicated that the ecological condition of Paisuni river was more suited for growth of T. tor in juvenile stage (1 and 2 year) but latter in adult stage (3 to 8 year) Tons river was most suited.

Figure 1. Plate 1 Key scales from dorsal fin region depicting age of Tor Mahseer, Tor tor ( $a-1+$ age, $b-5+$ age and $c-8+$ age).

Table 1. Mean length and growth rate of Mahseer, Tor tor at various ages estimated by scale methods in the Ken, Paisuni and Tons rivers Bundelkhand region.

\begin{tabular}{|c|c|c|c|c|c|c|}
\hline \multirow{2}{*}{ Age } & \multicolumn{2}{|l|}{ Ken river } & \multicolumn{2}{|l|}{ Paisuni river } & \multicolumn{2}{|l|}{ Tons river } \\
\hline & Mean length $(\mathrm{cm})$ & Growth rate $(\mathrm{cm})$ & Mean length $(\mathrm{cm})$ & Growth rate $(\mathrm{cm})$ & Mean length $(\mathrm{cm})$ & Growth rate $(\mathrm{cm})$ \\
\hline $1+$ & 20.2 & 20.2 & 22.8 & 22.8 & 20.8 & 20.8 \\
\hline $2+$ & 31.8 & 11.6 & 35.3 & 12.5 & 32.8 & 12 \\
\hline $3+$ & 39.8 & 8 & 43.7 & 8.4 & 42.9 & 10.1 \\
\hline $4+$ & 47.7 & 7.9 & 51.2 & 7.5 & 51.1 & 8.2 \\
\hline $5+$ & 54.9 & 7.2 & 58.6 & 7.4 & 58.4 & 7.3 \\
\hline $6+$ & 61 & 6.1 & 65.3 & 6.7 & 65.4 & 7 \\
\hline $7+$ & & & & & 73.2 & 7.8 \\
\hline $8+$ & & & & & 82 & 8.8 \\
\hline
\end{tabular}

The maximum growth percentage of $T$. tor was recorded in first year in the Paisuni river (34.91\%) compared to Ken river $(33.11 \%)$ and Tons river $(25.36 \%)$. The growth percentage varied from age to age (Figure 2). Overall lowest growth percentage was observed in Tons river with $8.54 \%$. The growth compensation was estimated in Tons river $T$. tor in $7+$ and $8+$ age classes (Plate 1).

Though it attains very big in size but the rate of growth $T$. tor in comparison to Indian major carps is slow. The present maximum recorded total length of $T$. tor was smaller compared to earlier reports. The fishing pressure, size of nets, fishing technique (example degree) and water quality are mostly responsible for decreasing of size and age classes of the fishes and recruitment (example damage breeding ground) in the lotic ecosystems [8,21-25]. It grow well both in the lentic and lotic environments and performs better growth in the lotic ecosystem.

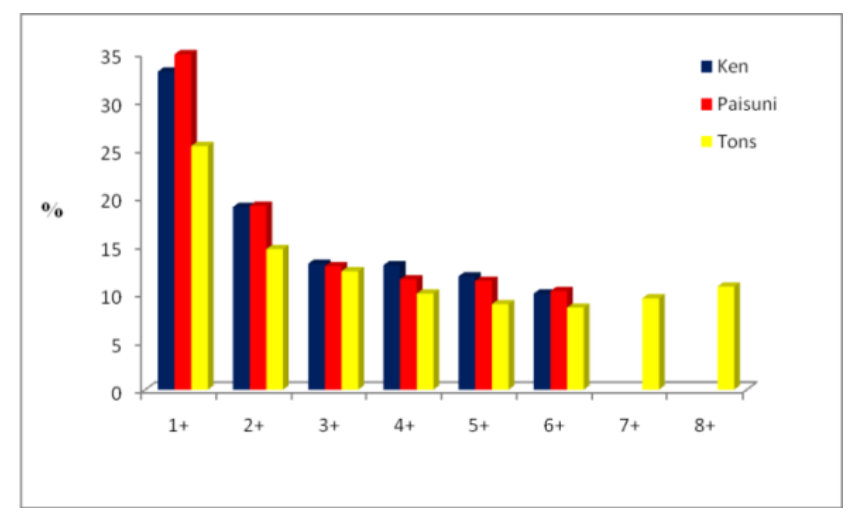

Figure 2. Growth increment (\%) of Mahseer, T. tor from the Ken, Paisuni and Tons rivers.

Age play a significant role determining growth and reproductive characteristics of fish [26-29]. The growth increments of fishes are indication of suitability of habitat and environmental condition of the ecosystem [29-30]. Growth rate indicated that the Paisuni river is more suitable for $T$. tor 
fishery in early stage. Religious place has provided sanctuary to T. tor in the Paisuni river [8,31-32]. Desai et al. [9] Reported mean length of $T$. tor $21.4,28.9,36.2,42.9,49.0,53.8$ and 57.2 $\mathrm{cm}$ in 1 to 7 age by scale method from the Narmada river. [33] observed mean length 249, 320, 380, 440, 490, 533 and 580 $\mathrm{mm}$ in 1 to 7 age from the Narmada river. [18], using scales and opercular bones, also studied age and growth of $T$. tor from Lake Bhimtal.

\section{Conclusion}

The results showed slower growth of fish in this cold water lake as compared to that from the Ken, Paisuni and Tons rivers. During the first five years the fish grew to 127.3, 242.0, 334.4, 414.6 and $478.0 \mathrm{~mm}$, respectively.

\section{Acknowledgement}

The author acknowledges the academic support and facilities provided by the Head, Department of Zoology, University of Allahabad, Prayagraj, Uttar Pradesh.

\section{References}

1. Das P, Pandey AK. Endangered fish species: measures for rehabilitation and conservation. Fish Chimes. 1999; 19: 31-34.

2. Khan MA, Sinha M. Status of mahseer fisheries in north and north-eastern India with a note on their conservation. J Inland Fish Indian. 2000; 31: 28-36.

3. Pinder AC, Britton JR, Harrison AJ, et al. Fishes of the world: status, challenges and opportunities for conservation. Rev Fish Biol Fisheries. 2019.

4. Dubey GP. Mahseer resources of Madhya Pradesh and its conservation with special reference to Narmada basin. $\mathrm{Pb}$ Fish Bull. 1985; 10: 12-18.

5. Dwivedi AC, Nautiyal P. Population dynamics of important fishes in the Vindhyan region, India. LAP Lambart Academic Publishing GmbH \& Co. KG, Germany. 2010; 1-220.

6. Nautiyal P, Dwivedi AC. Fishery in the tributaries of Yamuna river (Ken river, Paisuni river) and Ganga river (Tons river). J Mountain Res. 2019; 14: 19-36.

7. Chondar SL. Biology of finfish and shellfish. SCSC Publishers (India) Howrah, 1999; 1-514.

8. Dwivedi AC. Nautiyal P. Stock assessment of fish species Labeo rohita, Tor tor and Labeo calbasu in the Rivers of Vindhyan region, India. J Environ Biol. 2012; 33: 261-264.

9. Desai VR. Synopsis of biological data on the Tor mahseer Tor tor (Hamilton 1822). FAO (United Nations Rome), FAO Fisheries Synop. 2003; 158: 1-36.

10. Joshi KD, Biswas BK. Piscine diversity and fisheries in the river Ken, proposed for inter-river linking. J Inland Fish Indian. 2010; 42: 25-31.

11. Mayank P, Dwivedi AC. Resource use efficiency and invasive potential of non-native fish species, Oreochromis niloticus from the Paisuni River, India. Poul Fishe Wildlife Sci. $2017 ; 5$.
12. Kulkarni CV. Mahseer-the mighty game fish of India. Fish Chim. 1991; 43-49.

13. Pissolkar MD. Fishery and biology of Tor tor (Hamilton) from Govindgarh lake, Poona University, Pune. 1984.

14. Dubey GP. Endangered, vulnerable and rare fishes of west coast river system of India. In: Threatened Fishes of India. NACTON Publication Muzzafarnagar, 1994; 477-496.

15. Sasmal D, Qureshi TA. The bionomics of mahseer Tor tor and the cause of its decline in Narmada river system at Hoshangabad. J Inland Fish Indian. 1999; 31: 18-19.

16. Rizvi F, Dwivedi AC.,Singh KP. Study on population dynamics of Labeo calbasu (Ham.), suggesting conservational methods for optimum yield. Natl Acad Sci Lett. 2010; 33: 247-253.

17. Vilizzi L, Copp GH. Global patterns and clines in the growth of common carp Cyprinus carpio. J Fish Biol. 2017.

18. Pathani SS. On age and growth of the Mahseer, Tor tor (Hamilton) by scales. Matsya. 1986-87; 12-13: 194-198.

19. Bagenal TB, Tesch FW. Age and growth. In: Bagenal TB (ed) Methods for assessment of fish production in freshwater, 3rd edn. Blackwell Scientific Publication, Oxford, UK, 1978; 101-136.

20. Nautiyal P. Growth rate and age composition in relation to fishery, feeding and breeding ecology, pp 769-772. In Hirano, R. and Hanyu, I. (Eds.) Proc. 2nd Asian Fisheries Forum, Tokyo, Asian Fisheries Society, Manila, 1990.

21. Mayank P. Dwivedi AC. River health and commercially important catfishes from the Yamuna river, India. J Kalash Sci. 2015; 3: 23-26.

22. Dwivedi AC, Nautiyal P, Rizvi AF, et al. Landing scenario, size, age and population dynamic of Labeo rohita, Tor tor and L. calbasu response to need their restoration in the Vindhyan region, India. J Kalash Sci. 2016; 4: 27-40.

23. Mayank P. Dwivedi AC. Linking Cirrhinus mrigala (Hamilton, 1822) size composition and exploitation structure to their restoration in the Yamuna river, India. Asian J Bio Sci. 2016; 11: 292-297.

24. Tiwari A, Dwivedi AC, Mayank P. Time scale changes in the water quality of the Ganga River, India and estimation of suitability for exotic and hardy fishes. Hydrology Current Res. 2016; 7: 254.

25. Tripathi S, Gopesh A, Dwivedi AC. Fish and fisheries in the Ganga river : current assessment of the fish community, threats and restoration. J Exp Zool, India. 2017; 20: 907-912.

26. Weatherley AH, Gill HS. The biology of fish growth. Orlando, Florida Academy Press. 1987; 443.

27. Potts GW, Wootton RJ. Fish reproduction: strategies and tactics. New York, Academy Press. 1984.

28. Mayank P, Dwivedi AC. Biology of Cirrhinus mrigala and Oreochromis niloticus. LAP LAMBERT Academic Publishing GmbH \& Co. KG, Dudweiler Landstr. 99, 66123 Saarbrucken, Germany. 2015; 188.

29. Mayank P, Dwivedi AC, Pathak RK. Age, growth and age pyramid of exotic fish species Oreochromis niloticus 
Citation: Nautiyal P,Dwivedi AC. Growth rate determination of the endangered mahseer, tor tor (hamilton 1822) from the bundelkhand region, central India. J Fish Res 2021;5(3):1-4.

(Linnaeus 1758) from the lower stretch of the Yamuna river, India. Natl Acad Sci Lett 2018; 41: 345-348.

30. Dwivedi AC, Mayank P. Suitability of ecosystem determination through biology and marketing of exotic fish species, Oreochromis niloticus (Linnaeus, 1757) from the Ganga River, India. J Aquatic Res Marine Sci. 2018; 1: 69-75.

31. Nautiyal P, Dwivedi AC, Shivam A, et al. Possibility of breeding grounds of Mahseer in the Paisuni R. (Chitrakoot Dham): its ecology, and status of Tor tor (Hamilton) in the north Vindhyan rivers. J Bombay Natural Hist Soc. 2007; 104: 355-357.

32. Dwivedi AC. Mayank P. Tripathi S. Tiwari A. Biodiversity: the non-natives species versus the natives species and ecosystem functioning. J Biodiversity, Bioprospecting Devel. 2017; 4.

33. Karamchandani SJ, Desai VR, Pisolkar MD. Biological investigations on the fish and fisheries of Narmada river. Bull Cent Inland Fish Res Instt Barrackpore 1967; 19: 1-39.

*Correspondence to

Amitabh Chandra Dwivedi

Department of Zoology,

Nehru Gram Bharati, Prayagraj

Uttar Pradesh, India

E-mail: saajjjan@rediffmail.com 